\title{
Study of Continuous and Intermittent Drying of Pear Through Mathematical and Diffusion Models
}

\author{
Leiliane Silva Lopes Lima, Wilton Pereira da Silva (Corresponding Author), Joan Carlos \\ Alves Pereira, Cleide Maria Diniz P. S. e Silva \\ Federal University of Campina Grande, Campus I, PB, Brazil. Email: wiltonps@uol.com.br
}

Received: November 9, 2021 Accepted: December 13, 2021 Published: December 15, 2021

doi:10.5296/jas.v10i1.19331

URL: https://doi.org/10.5296/jas.v10i1.19331

\begin{abstract}
The methods for drying agricultural products are necessary to check the quality of the final product and feasibility of the process. The objective of this study was to perform the drying of pear by continuous and intermittent methods $(\alpha=2 / 3)$ at two different temperatures, compare the two methods and describe the processes using mathematical and diffusion models to evaluate the saving of time and effective processing energy. For continuous drying, Page model was the one which best fitted to the experimental data, with highest coefficient of determination and lowest chi-square. Regarding intermittent drying Page model was also the one which best fitted to the experimental data for the two temperatures studied. When comparing the drying methods studied, it was found that intermittent drying produced a similar and considerably better effect on the energy saving aspect, compared with continuous drying: $41.7 \%$ at $50{ }^{\circ} \mathrm{C}$ and $25.8 \%$ at $70{ }^{\circ} \mathrm{C}$. The effect of time intervals with the product out of the dryer, during the intermittent drying process, was reflected in the increase in the diffusion coefficient, so that the transport of moisture occurred more quickly for this type of drying, which contributes to justify the reduction of effective operating time and increased dry product quality.
\end{abstract}

Keywords: drying methods, Pyrus communis, infinite slab, diffusivity, energy saving

\section{Introduction}

Drying is a method of water removal used not only in the pharmaceutical (Pakowski and Mujumdar, 2007) and paper (Stenström, 2020) industries, but also in the ceramic (da Silva et al., 2013) and foodstuff (da Silva et al., 2011) industries, among others, being a fundamental method in the conservation of agricultural products after harvest.

Pear production in Brazil is still very modest, and the low quality of the fruit produced, due to the difficulty of finding cultivars that adapt to unfavorable climatic conditions, prevents this fruit from meeting the demands of the consumer market, so it is mostly (approximately 90\%) 
imported from countries such as Argentina, Chile and Portugal (Faoro and Orth, 2010; Fachinello et al., 2011; Revista Cultivar, 2020). The four Brazilian states that concentrate the production of pear, for providing the minimum conditions required by the crop, where harvests occur from February to April, are: Rio Grande do Sul, Santa Catarina, Paraná and São Paulo. According to Revista Cultivar (2020), pear is among the temperate climate fruits of greatest interest worldwide, being the most imported by Brazil.

In general, another relevant point as a bottleneck in agricultural production is post-harvest loss, mainly due to the ease of deterioration of these products, which still represents a major problem in the sector. In order to increase conservation time and reduce post-harvest losses, various conservation techniques are applied, and drying is one of the most requested. Studying different methods for drying agricultural products is necessary, in order to check both the quality of the final product and the feasibility of the process. Continuous drying is the one in which there is a permanent and continuous contact of product with hot air within the dryer. In intermittent drying, the product undergoes the action of heat, for a short period of time (continuous drying), then goes through a rest period (tempering period) without contact with the heated air, and then is subjected again to the continuous drying process (within the dryer), starting a new cycle. During the tempering period, the moisture content inside the product will be equalized through moisture diffusion. With this, the diffusion of water from the center to the periphery of the product and the evaporation of surface water occurs in a milder and more balanced way (Elias, 2002; Elias et al., 2010). It is worth mentioning the importance of studying problems involving the intermittent drying of solids with infinite slab geometry in order to evaluate the effect of process variables on the product and the use of diffusion and mathematical models to describe the fruit drying process.

\subsection{Intermittent Drying and Energy Efficiency}

Several studies show the efficiency of intermittent drying, both in terms of energy and in terms of improving the quality of the dried material. According to Putranto et al. (2011), intermittent drying reduces the effective drying time using hot air, thus reducing energy consumption per unit of removed mass, being an effective method to improve the drying rate and product quality. Pereira et al. (2020), in their study on the continuous and intermittent drying of rough rice, with intermittency ratio of $\alpha=2 / 3$, concluded that, in a comparison between continuous and intermittent drying kinetics, drying time was reduced with the application of intermittency, promoting greater energy saving. It was verified that the boundary condition of the first type was the one which best describes the drying process of rough rice and that the effective mass diffusivity increased with intermittent drying. The results showed that not only the intermittency ratio is important for the reduction of drying time, but also the tempering period. Silva et al. (2020), in their study on continuous and intermittent drying (with intermittency ratio of $\alpha=2 / 3$ ) with pieces of osmotically pretreated fresh apple, concluded that the proposed Page model described well all drying kinetic processes. For a given temperature, the comparison between the effective times of intermittent drying and continuous drying indicated that the intermittency leads to saving for all tempering periods, reaching up to $45 \%$. The authors also observed that, even for a single intermittency ratio, $\alpha=2 / 3$, the tempering period influenced the saving of effective drying 
time, hence saving of energy, and that the greatest saving occurred during the tempering period of $30 \mathrm{~min}$, while the worst result occurred for $120 \mathrm{~min}$.

Silva et al. (2015) performed the intermittent drying of whole bananas using hot air (with intermittency ratio of 1/2), for intermittency times of 30,60 and 120 minutes. The authors found that the Peleg model showed that eight hours of continuous drying are equivalent to four hours of discontinuous process with 1 hour of intermittency. In addition, this model made it possible to determine an expression for the drying rate and showed that the discontinuous process increases the value of this rate. The diffusion model with boundary condition of the third type described well the drying processes of mass transfer and showed that the Biot number was reduced from 11.5 (continuous) to 0.6 ( $1 \mathrm{~h}$ of intermittency), indicating that in intermittent drying the product is subjected to lower stresses.

Given the above, due to the technological interest in the fruit drying process for flour production, as well as the search for new options of food, the aim of this study was to perform the drying of pear (Pyrus communis), D'Anjou variety, by continuous and intermittent methods (intermittency ratio $=2 / 3$ ) at two different temperatures, compare the two methods and describe the processes using mathematical and diffusion models to evaluate the saving of time and effective processing energy.

\section{Method}

\subsection{Material and Experimental Procedures}

The experiments were carried out at the Laboratory of Storage and Processing of Agricultural Products (LAPPA), of the Academic Unit of Agricultural Engineering (UAEA) and at the Laboratory of Heat and Mass Transfer of the Academic Unit of Physics (UAF) of the Federal University of Campina Grande (UFCG), in Campina Grande-PB. The raw materials used were Argentine pears (Pyrus communis, D'Anjou variety), acquired in the local market of the city at the commercial maturity stage.

The fruits were selected based on appearance and absence of mechanical damage and carefully transported to the laboratory to start the experiments. Then, the fruits were sanitized and cut with a knife into circular slices with $5 \mathrm{~mm}$ thickness, measured with a digital caliper (Starrett brand) with precision of $0.001 \mathrm{~mm}$. The slices were placed in aluminum screen baskets $(15 \mathrm{~cm}$ x $13 \mathrm{~cm}$ size) and properly identified. These baskets had been previously weighed empty and then the whole set (pear + basket) was weighed to determine the initial total mass. The samples, in triplicate, were positioned in the center of the oven throughout the drying process to minimize the effect of the temperature gradient of the drying rate. Figure 1 illustrates the pears cut into circular slices (a), measurement of thickness with a caliper (b) and the slices arranged in the aluminum screen baskets (c). 

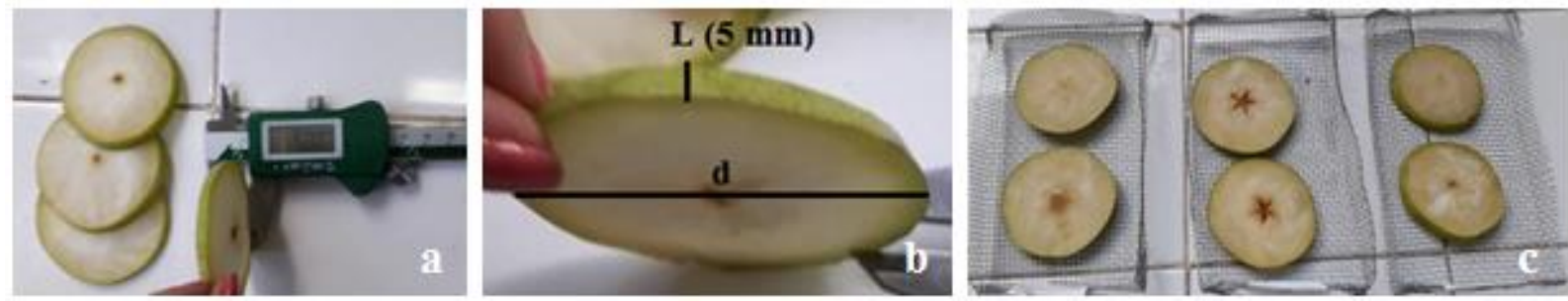

Figure 1. Pears cut into circular slices, measurement of thickness L and arrangement in aluminum screen baskets

Drying was carried out in a forced air circulation oven at drying air temperatures of 50 and 70 ${ }^{\circ} \mathrm{C}$ and average air speed of $1.0 \mathrm{~m} \mathrm{~s}^{-1}$. For continuous drying, the experimental data were obtained by weighing the baskets with the sample at time intervals of $0,5,10,15,20,25,30$, 60 min until the mass reached its equilibrium value. For intermittent drying, the samples were kept in the oven according to the stipulated time of intermittency (period inside the oven) and the stipulated time of tempering (period outside the oven).

Six experiments were carried out in total ( $E_{1}$ to $\left.E_{6}\right)$, two of continuous drying ( $E_{1}$ and $\left.E_{2}\right)$ and four of intermittent drying ( $E_{3}$ to $E_{6}$ ), with intermittency ratio of $\alpha=2 / 3$, defined from the expression $\alpha=t_{\text {out }} /\left(t_{\text {in }}+t_{\text {out }}\right)$. The terms "in" and "out" were used here to designate the entry and exit, respectively, of the sample in the oven without turning it off, and $t_{\text {in }}+t_{\text {out }}$ corresponds to the total time of one cycle (Silva et al., 2020). Upon reaching the mass equilibrium value, the samples of continuous and intermittent drying were taken to the oven at $105^{\circ} \mathrm{C}$ and kept for 24 hours to obtain the dry mass. Information about the experiments is presented in Table 1.

Table 1. Parameters for each pear drying experiment

\begin{tabular}{ccccc}
\hline Experiment & Drying & $\mathbf{t}_{\text {in }}(\mathbf{m i n})$ & $\mathbf{t}_{\text {out }}(\mathbf{m i n})$ & $\mathbf{T}\left({ }^{\circ} \mathbf{C}\right)$ \\
\hline $\mathrm{E}_{1}$ & Continuous & - & - & 50 \\
$\mathrm{E}_{2}$ & Continuous & - & - & 70 \\
\hline $\mathrm{E}_{3}$ & Intermittent & 10 & 20 & 50 \\
$\mathrm{E}_{4}$ & Intermittent & 10 & 20 & 70 \\
$\mathrm{E}_{5}$ & Intermittent & 15 & 30 & 50 \\
$\mathrm{E}_{6}$ & Intermittent & 15 & 30 & 70 \\
\hline
\end{tabular}

"in" and "out" designate inside the dryer and outside, respectively; $\mathrm{T}$ is the temperature.

The data of moisture on dry basis were used to calculate the values of moisture ratio (Equation 1) 


$$
\bar{X}^{*}=\frac{\bar{X}-X_{e q}}{X_{i}-X_{e q}}
$$

where,

$\overline{\mathrm{X}}^{*}$ - Moisture ratio of the product, dimensionless;

$\overline{\mathrm{X}}$ - Average moisture content of the product, dry basis;

$\mathrm{X}_{\mathrm{eq}}$ - Equilibrium moisture content of the product, dry basis;

$\mathrm{X}_{0}$ - Initial moisture content of the product, dry basis.

\subsection{Description of Drying Kinetics: Mathematical Models}

With the collected data, the drying kinetic curves were constructed and the mathematical models (Table 2) of Henderson and Pabis, Lewis, Newton, Page, Silva et alii, and Wang and Singh were fitted to the experimental data, using nonlinear regression through the curve fitting of LAB Fit Curve Fitting Software (Silva and Silva, 2009a).

Table 2. Mathematical models fitted to the data of continuous and intermittent drying kinetics

\begin{tabular}{lll}
\hline Model & Equation & Reference
\end{tabular}

Note: $\overline{\mathrm{X}}^{*}$ - Moisture ratio; $\mathrm{t}$ - Drying time (min); b - Drying constant; $\mathrm{a}$ - Coefficient of the models. 


\section{Macrothink

To describe the intermittent drying kinetics, data relative to the tempering periods were eliminated, and only data relative to the time the samples remained inside the oven (effective operating time) were analyzed. With this strategy, intermittent drying can be analyzed as "pseudo-continuous" drying (Cihan and Ece, 2001).

\subsection{Description of Drying Kinetics: Diffusion Model}

The Equation that describes the diffusion phenomenon for a generic variable $\Phi$, at rest medium (zero velocity), can be expressed as follows (Patankar, 1980; Beck et al., 1992; Maliska, 2004):

$$
\frac{\partial(\lambda \Phi)}{\partial t}=\operatorname{div}\left(\Gamma^{\Phi} \operatorname{grad}(\Phi)\right)+S
$$

where $\Phi$ is the dependent variable of interest (which can mean both moisture content or temperature), $\lambda$ and $\Gamma^{\Phi}$ are transport coefficients, and $\mathrm{S}$ is the source term.

The diffusion theory is based on Fick's law, which expresses the diffusion of moisture through the concentration gradient in the solid. Using Fick's law in the equation of water mass balance inside the product in the diffusion equation (8) leads to the equation for diffuse mass transport, according to Bird et al. (2001) and Maliska (2004):

$$
\frac{\partial X}{\partial t}=\operatorname{div}(D \operatorname{grad}(X))
$$

where,

$\mathrm{X}$ - Moisture content on dry basis;

D - Effective mass diffusivity;

$\mathrm{t}$ - time.

As the diameter of pear slices is much larger than the thicknesses previously established in the experiments $(5 \mathrm{~mm})$, the geometry considered for the product was that of an infinite slab. With this, the diffusion equation can be written for an infinite slab, as shown in Equation (10):

$$
\frac{\partial X}{\partial t}=\frac{\partial}{\partial t}\left(D \frac{\partial X}{\partial t}\right)
$$

where $\mathrm{X}$ is the moisture content on dry basis (or temperature), $\mathrm{t}$ is time, $\mathrm{x}$ defines the position within the infinite slab with respect to its center point, D (or $\alpha)$ is the effective diffusivity. 


\section{Macrothink}

2.4 Analytical Solution of Diffusion Equation for Infinite Slab With Boundary Condition of the Third Type

To describe the drying kinetics through a diffusion model, the initial and boundary conditions must be known. In general, the appropriate boundary condition for fruits described in the literature is that of the third type (Bennamoun and Belhamri, 2006; Esmaiili et al., 2007).

The boundary condition of the third type is expressed as follows:

$$
-\left.D \frac{\partial X(x, t)}{\partial x}\right|_{x= \pm \frac{L}{2}}=h\left[\left.X(x, t)\right|_{x= \pm \frac{L}{2}}-X_{e q}\right]
$$

where $\mathrm{h}$ is the convective mass transfer coefficient $\left(\mathrm{m} \mathrm{s}^{-1}\right) ; \mathrm{X}(\mathrm{x}, \mathrm{t})$ is the value of $\mathrm{X}$ in a position $\mathrm{x}$ at the instant $\mathrm{t}$; $\mathrm{X}_{\mathrm{eq}}$ is the equilibrium value of $\mathrm{X}$; and $\mathrm{L}$ is the infinite slab thickness (mm).

For the study of drying of pear slices through the analytical diffusion model, it was assumed that diffusion is the only water transport mechanism inside the product and that the initial distribution of moisture was uniform; the convective transfer coefficient and the effective mass diffusivity were considered constant during the process; the slices were considered homogeneous and isotropic and the thickness $\mathrm{L}$ did not vary during the process.

For the geometry of an infinite slab that is homogeneous, with thickness L, uniformly distributed initial moisture $\mathrm{X}_{0}$ and equilibrium moisture content $\mathrm{X}_{\mathrm{eq}}$, with a boundary condition defined by Equation (11), the analytical solution $\mathrm{X}(\mathrm{x}, \mathrm{t})$ of Equation (10) is provided by (Luikov, 1968; Crank, 1992):

$$
X(x, t)=X_{e q}+\left(X_{0}-X_{e q}\right) \sum_{n=1}^{\infty} A_{n} \cos \left(\mu_{n} \frac{x}{L / 2}\right) \exp \left(-\mu_{n}^{2} \frac{D}{(L / 2)^{2}} t\right)
$$

where the coefficients $A_{n}$ are given by:

$$
A_{n}=\frac{4 \sin \mu_{n}}{2 \mu_{n}+\sin \left(2 \mu_{n}\right)}
$$

where $\mu_{\mathrm{n}}$ are the characteristic roots of the equation

$$
\cot \mu_{n}=\frac{\mu_{n}}{B i}
$$

In Equation (14), $\mathrm{Bi}$ is the mass transfer Biot number, and it is by: 


$$
B i=\frac{h(L / 2)}{D}
$$

The average value of $X^{*}(x, t)$, denoted by $\bar{X}^{*}(t)$, is given by:

$$
\bar{X}^{*}(t)=\sum_{n=1}^{n t} B_{n} \exp \left(-\mu_{n}^{2} \frac{D}{(L / 2)^{2}} t\right)
$$

where the parameter $\mathrm{B}_{\mathrm{n}}$ is given by:

$$
B_{n}=\frac{2 B i^{2}}{\mu_{n}^{2}\left(B i^{2}+B i+\mu_{n}^{2}\right)}
$$

The roots of the transcendental equation (Equation 14) can be calculated for a specified Biot number. In order to determine the diffusivity and convective mass transfer coefficient or Biot number for a given set of experimental data, the optimization algorithm proposed by Silva et al. (2010) was applied in the present study, using 16 terms of the series.

\section{Results and Discussion}

\subsection{Experimental Results}

According to the results for continuous drying, the time required for the mass to reach its equilibrium was $1240 \mathrm{~min}$ for the sample at $50{ }^{\circ} \mathrm{C}\left(\mathrm{X}_{\mathrm{eq}}=0.128\right.$ d.b. $)$ and $880 \mathrm{~min}$ for the sample at $70{ }^{\circ} \mathrm{C}\left(\mathrm{X}_{\mathrm{eq}}=0.084 \mathrm{~d}\right.$.b. $)$. The increase in temperature caused reduction of drying time, and this phenomenon was already expected, since the higher the temperature used in the drying of agricultural products, the faster the process, and consequently the lower the final moisture content of the sample (d.b.). Silva and Azevedo (2016) also found that the increase in drying temperature reduced the time required for the fruits to reach the equilibrium moisture content. When comparing the intermittent drying with the continuous drying techniques, it was noted that the intermittent drying samples underwent a reduction in the total drying time for temperatures of 50 and $70{ }^{\circ} \mathrm{C}$, which indicates that the intermittent drying technique is more efficient in terms of reduction in drying time (effective operating time) and, consequently, energy saving.

\subsection{Results Obtained by the Mathematical Models}

Using the computer program LAB Fit Curve Fitting Software (Silva and Silva, (2009a), the equations described in Table 1 were applied to the experimental data to obtain the mathematical fit of the pear drying curves. In the analysis of the results, the coefficient of determination $\left(\mathrm{R}^{2}\right)$ and the chi-square $\left(\chi^{2}\right)$ were used as statistical indicators. The parameters of the mathematical models fitted to the data of continuous drying at temperatures of 50 and $70{ }^{\circ} \mathrm{C}$ are presented in Table 3. 
Table 3. Parameters of the different mathematical models for continuous drying at temperatures of 50 and $70{ }^{\circ} \mathrm{C}$

$\mathbf{T}$

$\left({ }^{\circ} \mathrm{C}\right)$

Models

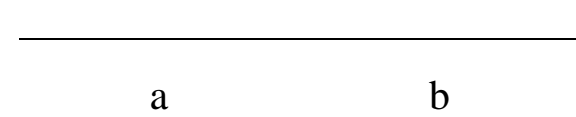

$\mathbf{R}^{2}$

$\chi^{2}$

\begin{tabular}{|c|c|c|c|c|c|}
\hline \multirow{7}{*}{50} & Henderson and Pabis & $0.103959 \times 10$ & $0.432233 \times 10^{-2}$ & 0.993610 & $0.406143 \times 10^{-1}$ \\
\hline & Lewis & $0.410289 \times 10^{-2}$ & - & 0.994492 & $0.521383 \times 10^{-1}$ \\
\hline & Page & $0.112439 \times 10^{-2}$ & $0.123928 \times 10$ & 0.998542 & $0.917082 \times 10^{-2}$ \\
\hline & & & & & \\
\hline & Peleg & $0.213750 \times 10^{3}$ & 0.749615 & 0.982845 & 0.101853 \\
\hline & Silva et alii & $0.519656 \times 10^{-2}$ & $-0.154057 \times 10^{-1}$ & 0.996009 & $0.244730 \times 10^{-1}$ \\
\hline & Wang and Singh & $-0.266581 \times 10^{-2}$ & $0.160569 \times 10^{-5}$ & 0.977213 & 0.158837 \\
\hline \multirow{7}{*}{70} & Henderson and Pabis & $0.104557 \times 10$ & $0.761670 \times 10^{-2}$ & 0.995213 & $0.238322 \times 10$ \\
\hline & Lewis & $0.719996 \times 10^{-2}$ & - & 0.995762 & $0.347574 \times 10^{-1}$ \\
\hline & Page & $0.245048 \times 10^{-2}$ & $0.121970 \times 10$ & 0.999347 & $0.318912 \times 10^{-2}$ \\
\hline & & & & & \\
\hline & Peleg & $0.114490 \times 10^{3}$ & 0.787220 & 0.979324 & 0.101583 \\
\hline & Silva et alii & $0.916638 \times 10^{-2}$ & $-0.214842 \times 10^{-1}$ & 0.997691 & $0.112061 \times 10^{-1}$ \\
\hline & Wang and Singh & $-0.414899 \times 10^{-2}$ & $0.370327 \times 10^{-5}$ & 0.950078 & 0.307605 \\
\hline
\end{tabular}

Note: $\mathrm{a}$ and $\mathrm{b}$ - fitting parameters; $\mathrm{R}^{2}$ - determination coefficient; $\chi^{2}$ - chi-square

According to the results presented in Table 3, Page model was the one which best fitted to the experimental drying data for the two temperatures studied, showing the highest coefficients of determination $\left(\mathrm{R}^{2} \geq 0.998\right)$ and lowest chi-squares $\left(\chi^{2} \leq 0.9170 \times 10^{-2}\right)$, which indicates that this model satisfactorily represents the drying of the pear cut into slices, for both temperatures. In the sequence, the model that also showed good fits for the two temperatures studied was Silva et alii, followed by Lewis and Henderson and Pabis. Among the mathematical models analyzed, Peleg and Wang and Singh had the lowest coefficients of determination $\left(\mathrm{R}^{2} \geq 0.98\right)$, indicating less satisfactory fits for the two temperatures.

Good fits for Page model were found by Alexandre et al. (2013), in the drying kinetic curves of enriched pineapple residue, with slightly higher $\mathrm{R}^{2}$ values and the lowest $\chi^{2}$ values for 
temperatures of 40,50 and $60{ }^{\circ} \mathrm{C}$, fitting better to the observed data, compared with the models of Hendersonand Pabis and Lewis, and by Silva et al. (2014), in the thin-layer drying of whole bananas, for which Page and Silva et alii were the models that described well the drying kinetics at temperatures of $40,50,60$ and $70{ }^{\circ} \mathrm{C}$.
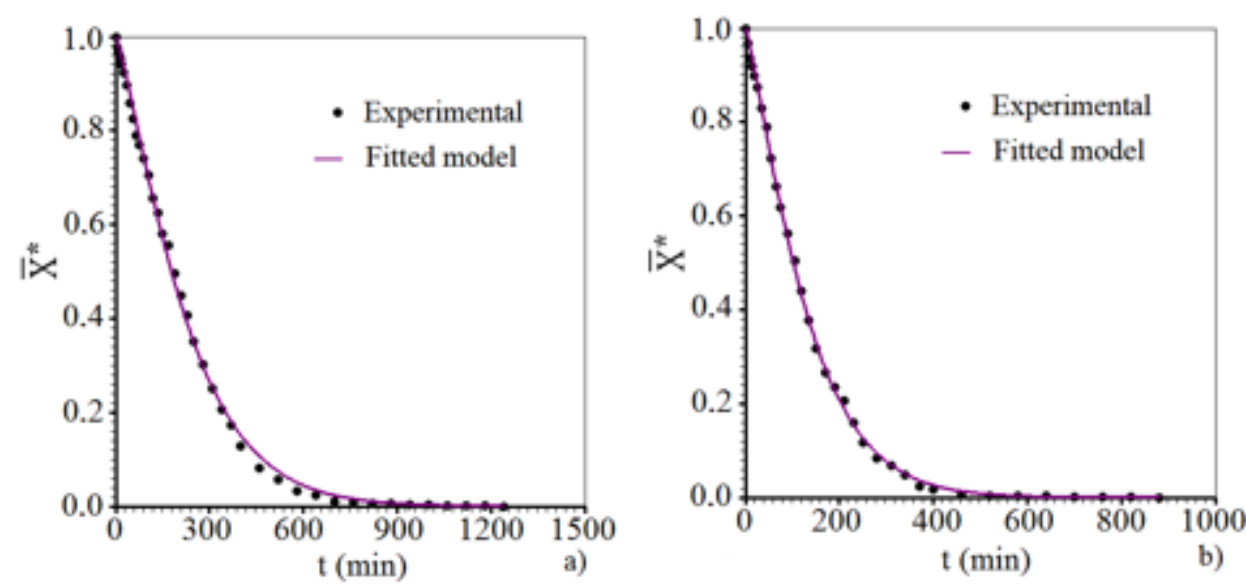

Figure 2. Continuous drying kinetics for Page model at temperatures of: (a) $50{ }^{\circ} \mathrm{C}$; (b) $70{ }^{\circ} \mathrm{C}$

Graph (a) in Figure 2 shows the behavior of the curve that best fitted to the experimental data for the temperature of $50{ }^{\circ} \mathrm{C}$ and graph (b) shows the best behavior of the curve for the temperature of $70^{\circ} \mathrm{C}$. Based on the graphs shown in Figure 2, it was clearly found that the drying time decreased more rapidly with the increase of temperature from 50 to $70{ }^{\circ} \mathrm{C}$, thus promoting the decrease in moisture content ( $\mathrm{X}_{\mathrm{eq}}$ ), from 0.128 (d.b.) to 0.084 (d.b.), respectively. For the intermittent drying processes, the intermittent periods were eliminated from the experimental data, and the empirical equations in Table 2 were again fitted to the new experimental data sets as pseudo-continuous fits. The obtained results are presented in Table 4.

Table 4. Parameters of the different mathematical models for intermittent drying at temperatures of 50 and $70{ }^{\circ} \mathrm{C}$

\begin{tabular}{|c|c|c|c|c|c|c|}
\hline & \multirow{2}{*}{$\begin{array}{c}\mathbf{T} \\
\left({ }^{\mathbf{o}} \mathbf{C}\right)\end{array}$} & \multirow{2}{*}{ Models } & \multicolumn{2}{|c|}{ Parameters } & \multirow{2}{*}{$\mathbf{R}^{2}$} & \multirow{2}{*}{$\chi^{2}$} \\
\hline & & & $\mathbf{a}$ & b & & \\
\hline \multirow{6}{*}{$\begin{array}{c}\text { Inter. } \\
\mathrm{t}_{\mathrm{in}}=10 \\
\min \end{array}$} & \multirow{6}{*}{50} & Henderson/Pabis & $0.10975236195 \times 10^{-1}$ & $0.76701641690 \times 10^{-2}$ & 0.9871776 & 0.142989 \\
\hline & & Lewis & $0.70389503025 \times 10^{-2}$ & - & 0.9917487 & 0.216474 \\
\hline & & Page & $0.12956083338 \times 10^{-2}$ & $0.13281341896 \times 10$ & 0.9978937 & $0.217531 \times 10^{-1}$ \\
\hline & & Peleg & $0.14555697152 \times 10^{3}$ & 0.63866137374 & 0.9864143 & 0.133809 \\
\hline & & Silva et alii & $0.97503177919 \times 10^{-2}$ & $0.34100979165 \times 10^{-1}$ & 0.9928167 & $0.757240 \times 10^{-1}$ \\
\hline & & Wang and Singh & $0.49715713298 \times 10^{-2}$ & $0.61512090224 \times 10^{-5}$ & 0.9976750 & $0.210889 \times 10^{-1}$ \\
\hline
\end{tabular}




\section{II Macrothink}

Journal of Agricultural Studies

ISSN 2166-0379

2022, Vol. 10, No. 1

\begin{tabular}{|c|c|c|c|c|c|c|}
\hline & & Henderson/Pabis & $0.11052320436 \times 10$ & $0.10675212416 \times 10^{-1}$ & 0.9886899 & 0.107807 \\
\hline & & Lewis & $0.97543231900 \times 10^{-2}$ & - & 0.9914868 & 0.171872 \\
\hline & & Page & $0.18901658437 \times 10^{-2}$ & $0.13386088112 \times 10$ & 0.9981275 & $0.157698 \times 10^{-1}$ \\
\hline & 10 & Peleg & $0.92506261012 \times 10^{2}$ & 0.72803466113 & 0.9734113 & 0.229766 \\
\hline & & Silva et alii & $0.13760669857 \times 10^{-1}$ & $0.43112288110 \times 10^{-1}$ & 0.9942771 & $0.517678 \times 10^{-1}$ \\
\hline & & Wang and Singh & $0.63425846656 \times 10^{-2}$ & $0.96042194206 \times 10^{-5}$ & 0.9845670 & 0.140302 \\
\hline & & Henderson/Pabis & $0.11131947472 \times 10$ & $0.61158592777 \times 10^{-2}$ & 0.9737029 & 0.293723 \\
\hline & & Lewis & $0.55203036496 \times 10^{-2}$ & - & 0.9821804 & 0.414724 \\
\hline & & Page & $0.53814920127 \times 10^{-3}$ & $0.14347951942 \times 10$ & 0.9937359 & $0.671311 \times 10^{-1}$ \\
\hline & & Peleg & $0.22422296104 \times 10^{3}$ & 0.46716389762 & 0.9928053 & $0.737046 \times 10^{-1}$ \\
\hline & & Silva et alii & $0.80840672659 \times 10^{-2}$ & $0.35541826110 \times 10^{-1}$ & 0.9831181 & 0.180453 \\
\hline & & Wang and Singh & $0.39383998038 \times 10^{-2}$ & $0.37625895606 \times 10^{-5}$ & 0.9983396 & $0.188993 \times 10^{-1}$ \\
\hline & & Henderson/Pabis & $0.11163484387 \times 10$ & $0.10316915632 \times 10^{-1}$ & 0.9845234 & 0.145558 \\
\hline Inter. & & Lewis & $0.93448377889 \times 10^{-2}$ & - & 0.9893113 & 0.226834 \\
\hline $\mathrm{t}_{\mathrm{in}}=15$ & & Page & $0.13602664195 \times 10^{-2}$ & $0.13947519320 \times 10$ & 0.9974773 & $0.213522 \times 10^{-1}$ \\
\hline & & Peleg & $0.10659019684 \times 10^{3}$ & 0.66312806644 & 0.9774904 & 0.190319 \\
\hline & & Silva et alii & $0.13600614226 \times 10^{-1}$ & $0.46658015695 \times 10^{-1}$ & 0.9917808 & $0.736489 \times 10^{-1}$ \\
\hline & & Wang and Singh & $0.64596212030 \times 10^{-2}$ & $0.10203415682 \times 10^{4}$ & 0.9953469 & $0.353485 \times 10^{-1}$ \\
\hline
\end{tabular}

According to the results shown in Table 4, for intermittent drying ( $\operatorname{tin}_{1}=10 \mathrm{~min}$ ) at both 50 and $70{ }^{\circ} \mathrm{C}$, Page model showed the best coefficients of determination $\left(\mathrm{R}^{2}\right)$ and chi-square $\left(\chi^{2}\right)$, respectively $\mathrm{R}^{2} \geq 0.997$ and $\chi^{2} \leq 0.217 \times 10^{-1}$. In the sequence, Wang and Singh model for the temperature of $50{ }^{\circ} \mathrm{C}\left(\mathrm{R}^{2}=0.997\right.$ and $\left.\chi^{2}=0.210 \times 10^{-1}\right)$ and Silva et alii for the temperature of $70{ }^{\circ} \mathrm{C}\left(\mathrm{R}^{2}=0.994\right.$ and $\left.\chi^{2}=0.517 \times 10^{-1}\right)$ were also satisfactory to describe the intermittent drying kinetics of pear slices.

For intermittent drying ( $\mathrm{t}_{\mathrm{in}}=15 \mathrm{~min}$ ), better fits were shown by Wang and Singh model, to the experimental data for $\mathrm{T}=50{ }^{\circ} \mathrm{C}$, followed by Page model, with $\mathrm{R}^{2}$ value of 0.993 . It was verified that the coefficients of determination for the models mentioned were higher than 0.99 , indicating that they are able to accurately predict the behavior of the product in relation to moisture loss during the drying process. For the temperature of $70{ }^{\circ} \mathrm{C}$, Page model stood out, with highest coefficient of determination $\left(\mathrm{R}^{2}\right)$ and lowest chi-square $\left(\chi^{2}\right)$, followed by Wang and Singh model. Figure 3 shows the simulations of intermittent drying kinetics, with cycles 


\section{Macrothink

involving the time of $10 \mathrm{~min}$ inside the oven $\left(\mathrm{t}_{\mathrm{in}}=10 \mathrm{~min}\right)$ and $20 \mathrm{~min}$ outside the oven $\left(\mathrm{t}_{\text {out }}=\right.$ $20 \mathrm{~min}$ ), in the desiccator. These kinetic processes were obtained using the Page model for temperatures of 50 and $70{ }^{\circ} \mathrm{C}$
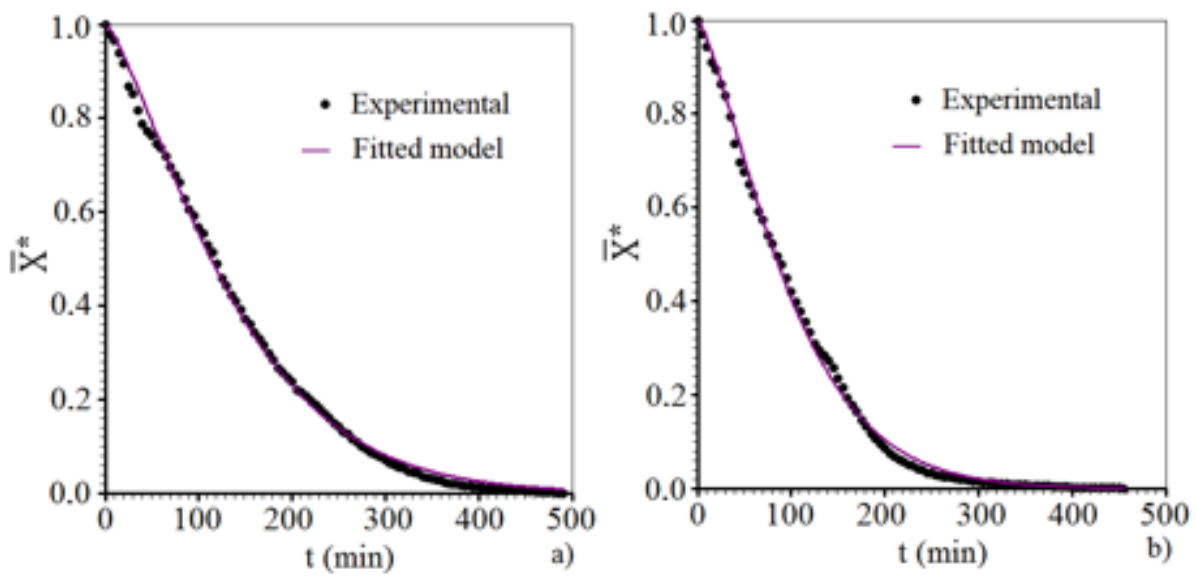

Figure 3. Intermittent drying kinetics ( $\mathrm{t}_{\mathrm{in}}=10 \mathrm{~min}$ ) for Page model at temperatures of: (a)

$$
50{ }^{\circ} \mathrm{C} \text {; (b) } 70{ }^{\circ} \mathrm{C}
$$

Page model is generally used successfully to describe the drying kinetics of various agricultural products. Lima et al. (2020) carried out experiments with continuous and intermittent drying of sapodilla, at temperatures of 50 and $70{ }^{\circ} \mathrm{C}$, and concluded that Page model was the best to estimate the drying kinetic curves of this fruit for the two temperatures studied.

Figure 4 shows the simulation of intermittent drying kinetics, with cycles involving the time of $15 \mathrm{~min}$ inside the oven ( $\mathrm{t}_{\mathrm{in}}=15 \mathrm{~min}$ ) and $30 \mathrm{~min}$ outside the oven ( $\mathrm{t}_{\text {out }}=30 \mathrm{~min}$ ), in the desiccator. This kinetic process was obtained using the Wang and Singh model for the temperature of $50{ }^{\circ} \mathrm{C}$.

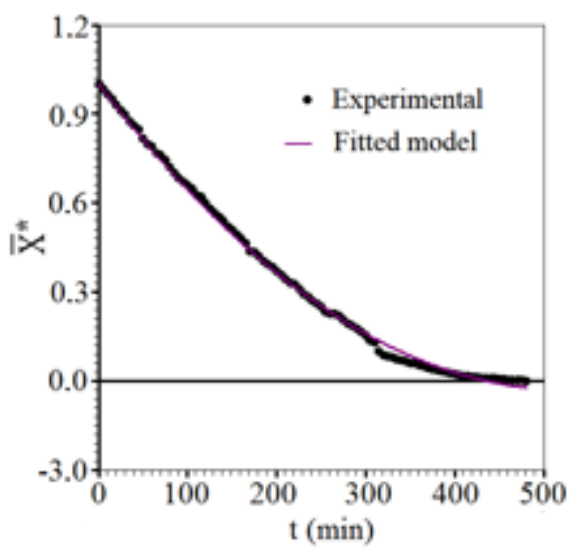

Figure 4. Intermittent drying kinetics $\left(\mathrm{t}_{\mathrm{in}}=15 \mathrm{~min}\right)$ for Wang and Singh model at $50{ }^{\circ} \mathrm{C}$

According to the results presented in Table 4 for intermittent drying, with intermittency $t_{\text {in }}=$ $15 \mathrm{~min}$, there was good fit of the Wang and Singh model to the experimental data for $\mathrm{T}=50{ }^{\circ} \mathrm{C}$. However, as Figure 4 shows, this model presents negative moisture ratios in the 
final part of the process, and this fact is physically inconsistent and. for that, the model must be disregarded. Thus, Page model, with $\mathrm{R}^{2}$ value of 0.993 can be pointed as the best model. The coefficient of determination for Page model was higher than 0.99, indicating that this model is able to accurately predict the behavior of the product in relation to moisture loss during the drying process. For the temperature of $70{ }^{\circ} \mathrm{C}$, Page model stood out, with the highest coefficient of determination $\left(\mathrm{R}^{2}\right)$ and lowest chi-square $\left(\chi^{2}\right)$, followed by Wang and Singh model, as can be observed in Table 4. Obviously, with Table 4, similar graphs obtained for $t_{\text {in }}=10 \mathrm{~min}$ could be obtained for $t_{\text {in }}=15 \mathrm{~min}$. However, in this article only the superposition for all experimental situations at each temperature is presented as it is shown below.

The graph in Figure 5 below represents the superposition of continuous and intermittent drying kinetics of pear at temperatures of $50{ }^{\circ} \mathrm{C}$ (a) and $70{ }^{\circ} \mathrm{C}(\mathrm{b})$, and Page model was chosen to represent the drying processes, as it showed a good agreement between the experimental and the simulated data.
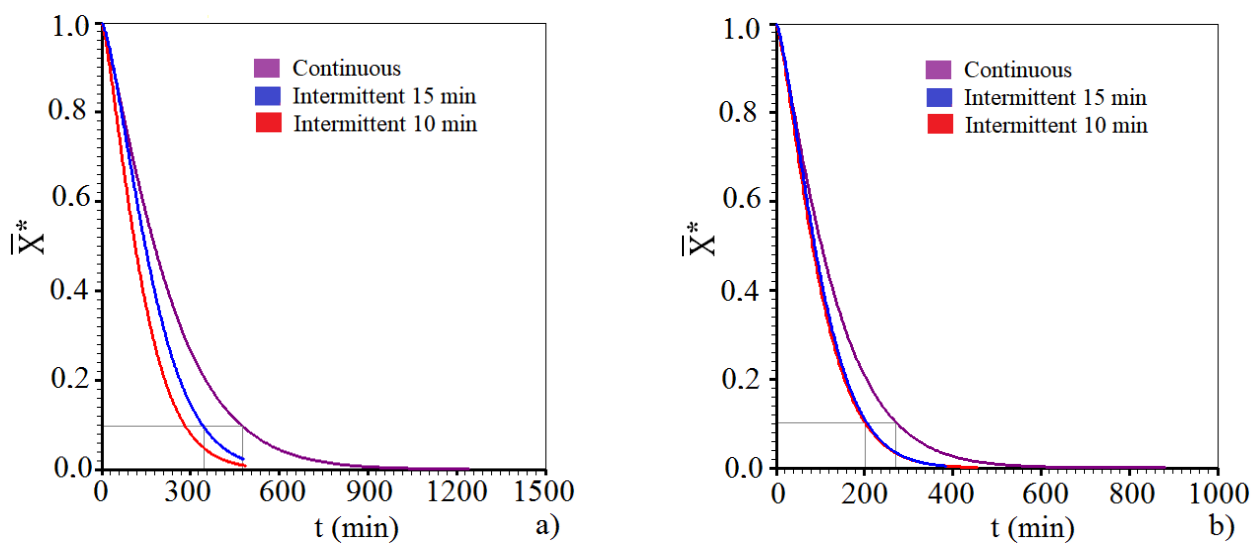

Figure 5. Superposition of the continuous and intermittent drying kinetics of pear described by the Page model for drying air temperatures of: (a) $50{ }^{\circ} \mathrm{C}$; (b) $70{ }^{\circ} \mathrm{C}$

Regarding the temperature of $50{ }^{\circ} \mathrm{C}$, Figure 5 (a), the intermittent drying time ( $\mathrm{t}_{\text {in }}=15 \mathrm{~min}$ ) was about $350 \mathrm{~min}$ to reach the moisture ratio of 0.1 , while for continuous drying the corresponding time was of $480 \mathrm{~min}$. Thus, it can be stated that the intermittent drying process $\left(\mathrm{t}_{\mathrm{in}}=15 \mathrm{~min}\right)$ at a temperature of $50^{\circ} \mathrm{C}$ obtained the effective drying time with a difference of 130 min less than continuous drying at the same temperature. This way, intermittent process was about $27.1 \%$ more efficient, that is, there was a saving of $27.1 \%$ in time and, consequently, in energy, since the dryer works with constant power (constant temperature). Figure 5 (a) also indicates that, for intermittent drying with tin $=10 \mathrm{~min}$, time (and energy) savings is $41.7 \%$, Some vitamins contained in fruits are heat sensitive, so reducing the time of exposure to heat contributes to product quality. On the other hand, for the temperature of 70 ${ }^{\circ} \mathrm{C}$, Figure $5(\mathrm{~b})$, the intermittent process $\left(\mathrm{t}_{\mathrm{in}}=10 \mathrm{~min}\right.$ and $\mathrm{t}_{\mathrm{in}}=15 \mathrm{~min}$ ) was about $204 \mathrm{~min}$ to reach the moisture ratio of 0.1 , while for continuous drying the corresponding time was 275 min. The time difference was 71 min less for the intermittent process, that is, $25.8 \%$ more efficient than the continuous process. In general, it was found that all intermittency levels studied here, with intermittency ratio $\alpha=2 / 3$, had similar final process times, proving to be 
efficient in relation to energy consumption. Pereira et al. (2020), in the drying of rough rice, also showed that intermittent drying produced a similar effect on drying kinetics, highlighting the feasibility of using intermittent drying of rough rice with intermittency ratio $\alpha=2 / 3$ for temperatures of 50 and $70{ }^{\circ} \mathrm{C}$. The results also suggest that the 30 -min tempering period was more adequate than the 20 -min tempering period. The effect of tempering period is related to the reduction of moisture gradients during this time, so the more intense the decrease in moisture gradients during the tempering period, the greater the reduction of consumed energy at the end of the process.

\subsection{Results Obtained by the Diffusion Model}

The software program used for the analytical solution of the diffusion equation to simulate the drying kinetics of pear was the "Convective Adsorption - Desorption" V. 2.4 (Silva and Silva, 2009b), for the boundary condition of the third type. Table 5 describes the parameters obtained in the simulation of the drying process of pear slices, using the diffusion model with boundary condition of the third type for infinite slab geometry.

Table 5. Parameters obtained through simulations using analytical solution with boundary condition of the third type

\begin{tabular}{ccccccc}
\hline $\begin{array}{c}\mathbf{T} \\
\left({ }^{\circ} \mathbf{C}\right)\end{array}$ & $\begin{array}{c}\text { Experiment } \\
(\mathbf{m i n})\end{array}$ & $\begin{array}{c}\mathbf{D}\left(\mathbf{1 0}^{-\mathbf{5}}\right) \\
\left(\mathbf{m}^{\mathbf{2}} \mathbf{.} \mathbf{m i n}^{-\mathbf{1}}\right)\end{array}$ & $\begin{array}{c}\mathbf{h}\left(\mathbf{1 0}^{-5}\right) \\
\left(\mathbf{m} \cdot \mathbf{m i n}^{-\mathbf{1}}\right)\end{array}$ & $\boldsymbol{B i}\left(\mathbf{1 0}^{-3}\right)$ & $\mathbf{R}^{\mathbf{2}}$ & $\chi^{\mathbf{2}}$ \\
\hline 50 & Continuous & 1.8741 & 1.1222 & 1.5000 & 0.9940 & $3.8823 \times 10^{-2}$ \\
70 & Continuous & 3.2641 & 1.9584 & 1.5000 & 0.9959 & $2.1868 \times 10^{-2}$ \\
50 & Intermittent 10 & 3.1182 & 1.8784 & 1.5000 & 0.9908 & 0.1624 \\
70 & Intermittent 10 & 4.3343 & 2.6058 & 1.5000 & 0.9917 & 0.1269 \\
50 & Intermittent 15 & 2.4872 & 1.4893 & 1.5000 & 0.9806 & 0.3473 \\
70 & Intermittent 15 & 4.1682 & 2.5000 & 1.5000 & 0.9891 & 0.1741 \\
\hline
\end{tabular}

In general, according to the results presented in Table 5, it was possible to verify that the diffusion model showed good statistical indicators and a satisfactory fit between the applied simulations, despite the low Biot numbers. These statistical indicators are comparable to those using the Page's model and therefore similar graphs to Page would be obtained using the diffusion models. For that, these graphs were not presented in this article. When comparing the results of continuous drying, it is possible to verify that the diffusivity at the temperature of $70{ }^{\circ} \mathrm{C}$ was higher than that at the temperature of $50{ }^{\circ} \mathrm{C}$, that is, D $\left(3.2641 \times 10^{-5}>1.8741 \times 10^{-5}\right)$. The statistical indicators for the temperature of $70{ }^{\circ} \mathrm{C}$ were also better, with $\mathrm{R}^{2}(0.9959>9940$, for instance $)$ and $\chi^{2}\left(2.1868 \times 10^{-2}<3.8823 \times 10^{-2}\right.$, for instance $)$. Costa et al. (2015) also found that the effective diffusion coefficient increased with increasing 
temperature, during the drying of crambe fruits. Almeida et al. (2020), in the drying of melon seed, observed that the effective diffusivity values increased from $6.78 \times 10^{-10} \mathrm{~m}^{2} . \mathrm{min}^{-1}$ to $8.82 \times 10^{-10} \mathrm{~m}^{2}$. $\min ^{-1}$ when the drying temperature increased from $50{ }^{\circ} \mathrm{C}$ to $70{ }^{\circ} \mathrm{C}$.

According to Alves et al. (2019), the effective diffusivity indicates the speed at which water can be transferred from the inside to the surface of the product. Regarding intermittent drying, it is possible to verify that diffusivity also increased with the increase in temperature, that is, it was higher at $70{ }^{\circ} \mathrm{C}$, both for the intermittency of $10 \mathrm{~min}$ and for the intermittency of 15 min, with values of $4.3343 \times 10^{-5}$ and $4.1682 \times 10^{-5}$, respectively.

When comparing continuous drying and intermittent drying at $50{ }^{\circ} \mathrm{C}$, one can note that the diffusivity value of continuous drying is lower than the diffusivity value of the two intermittent drying processes ( $t_{i n}=10 \mathrm{~min}$ and $t_{i n}=20 \mathrm{~min}$ ). The same occurred for diffusivity at $70{ }^{\circ} \mathrm{C}$, at which the value for continuous drying was lower than the value of the two intermittent drying processes. It can be concluded that the effect of tempering period on the intermittent drying process of pear was reflected in the increase of the diffusion coefficient, so the transport of moisture occurs more quickly for the intermittent drying process, which contributes to justifying the reduction of the effective operating time. It is worth pointing out that the diffusion model for convective boundary condition (third type) predicts that there may be resistance to water flow on the outer surface of the pear; thus, the process is governed not only by the effective mass diffusivity (D), but also by the convective mass transfer coefficient (h). As with the effective diffusivity, the convective mass transfer coefficient showed a direct relationship with the increase in drying temperature.

It can be noted that the convective mass transfer coefficient is higher among the continuous drying processes for the higher temperature, with $\mathrm{h}\left(1.9584 \times 10^{-5}>1.1222 \times 10^{-5}\right)$, temperatures of 50 and $70{ }^{\circ} \mathrm{C}$, respectively. The same phenomenon occurred among the intermittent drying processes at the two studied temperatures, but with the difference that for intermittent drying $\left(\mathrm{t}_{\mathrm{in}}=10 \mathrm{~min}\right.$ ) the convective mass transfer coefficient increased, both at 50 and $70{ }^{\circ} \mathrm{C}$. The best statistical indicators $\left(\mathrm{R}^{2}\right.$ and $\left.\chi^{2}\right)$ were obtained for the temperature of 70 ${ }^{\circ} \mathrm{C}$ with intermittent drying $\left(\mathrm{t}_{\mathrm{in}}=10 \mathrm{~min}\right.$ ). In view of the results presented, it can be stated that the boundary condition of the third type is adequate to describe the drying of pear slices.

Another parameter that arises with the use of the boundary condition of the third type is the Biot number, which serves to extract information about the distribution of moisture during drying. According to Kaya et al. (2010) and Ferreira et al. (2020), the Biot number indicates the existence of internal factors and external resistances to water transfer, being considered the most realistic case in practical applications. It is possible to note that the Biot number was low in all experiments, indicating homogeneity and distribution of moisture within the product, which favors the increase in the quality of the final product.

\section{Conclusion}

The analysis of the results made it possible to conclude that:

(1) Among the mathematical models for continuous drying, Page was the one which best fitted to the experimental data. 
(2) Regarding intermittent drying, Page model was also the one which best fitted to the experimental data for the two temperatures studied.

(3) Intermittent drying produced a considerably better effect on the energy saving aspect, compared with continuous drying. The experiment with intermittent drying resulted in a $41.7 \%\left(50^{\circ} \mathrm{C}\right)$ and $25.8\left(70^{\circ} \mathrm{C}\right)$ reduction in effective drying time compared with continuous drying at same temperature

(4) The effect of tempering period on the intermittent drying process was reflected in the increase in the diffusion coefficient, which contributes to justifying the reduction of the effective operating time.

\section{References}

Alexandre, V. H., Silva, F. L. H., Gomes, J. P., Silva, O. S., Carvalho, J. P. D., \& Lima, E. E. (2013). Cinética de secagem do resíduo de abacaxi enriquecido. Revista Brasileira de $\begin{array}{llll}\text { Engenharia Agrícola } \quad e \quad \text { Ambiental, } & \text { 17(6), }\end{array}$ https://doi.org/10.1590/S1415-43662013000600010

Almeida, R. L. J., Santos, N. C, Pereira, T. S., Silva, V. M. A., Ribeiro, V. H. A, Silva, L. R. I., ... \& Eduardo, R. S. (2020). Cinética de secagem de sementes de melão descrita por um modelo de difusão. Research, Society and Development, 9(5). e32953146. https://doi.org/10.33448/rsd-v9i5.3146

Alves, R. A., Queiroz, A. J. D. M., Figueirêdo, R. M., Silva, W. P. D., \& Gomes, J. P. (2019). Secagem solar de feijão-caupi combinada com secagem em secador acumulador de calor. Revista Brasileira de Engenharia Agrícola e Ambiental, 23(9), 709-715. https://doi.org/10.1590/1807-1929/agriambi.v23n9p709-715

Beck, J. V, Cole, K. D., Haji-Sheikh, A., \& Litkouhi, B. (1992). Heat conduction using green's functions. New York: Hemisphere Publishing Corporation. Chapter ten: Galerkinbased green's functions and solutions, p. 293-335.

Bennamoun, L., \& Belhamri A. (2006). Numerical simulation of drying under variable external conditions: Application to solar drying of seedless grapes. Journal of Food Engineering, 76(2), 179 -187. https://doi.org/10.1016/j.jfoodeng.2005.05.005

Bird, R. B., Stewart, W. E., \& Lightfoot, E. N. (2001). Transport phenomena. 2nd Ed. New York: John Wiley \& Sons, Inc., p. 912.

Cihan, A., \& Ece, M. C. (2001). Liquid di_usion model for intermittent drying of rough rice. Jounal Food Engineering, 49, 327-331. https://doi.org/10.1016/S0260-8774(00)00230-2

Costa, L. M., Resende, O., Gonçalves, D. N., \& Oliveira, D. E. C. (2015). Modelagem matemática da secagem de frutos de crambe em camada delgada. Bioscience Journal, Uberlândia, 31(2), 392-403. https://doi.org/10.14393/BJ-v31n2a2015-22340

Crank, J. (1992). The Mathematics of Diffusion. Clarendon Press, Oxford, UK, p. 414. 
da Silva, W. P., e Silva, C. M. D. P. S., \& Lins, M. A. A. (2011). Determination of expressions for the thermal diffusivity of canned foodstuffs by the inverse method and numerical simulations of heat penetration. International Journal of Food Science and Technology, 46(4), 811-818. https://doi.org/10.1111/j.1365-2621.2011.02552.x

da Silva, W. P., e Silva, C. M. D. P. S., da Silva, L. D., \& Farias, V. S. O. (2013). Drying of clay slabs: Experimental determination and prediction by two-dimensional diffusion models. Ceramics International, 39(7), 7911-7919. https://doi.org/10.1016/j.ceramint.2013.03.053

Diamante, L. M., Ihns, R., Savage, G. P., \& Vanhanen, L. (2010). A new mathematical model for thin layer drying of fruits. International Journal of Food Science and Technology, 45(9), 1956-1962. https://doi.org/10.1111/j.1365-2621.2010.02345.x

Elias, M. C. (2002). Tecnologias para armazenamento e conservação de grãos, em médias e pequenas escalas. $3^{\text {a }}$ Ed. Pelotas: Editora Universitária da UFPel, p. 218.

Elias, M. C., Oliveira, M., \& Schiavon, R. A. (2010). Qualidade de arroz na pós-colheita: Ciência, tecnologia e normas. Pelotas: Santa Cruz, 2010. p. 543.

Esmaiili, M., Rezazadeh, G., Sotudeh-Gharebagh, R., \& Tahmasebi, A. (2007). Modeling of the Seedless Grape Drying Process using the Generalized Differential Quadrature Method. Chemical Engineering Technology, 30, 168-175. https://doi.org/10.1002/ceat.200600151

Fachinello, J. C., Pasa, M. S., Schmtiz, J. D., \& Betemps, D. L. (2011). Situação e perspectivas da fruticultura de clima temperado no Brasil. Revista Brasileira de Fruticultura, 33(1), 109-120. https://doi.org/10.1590/S0100-29452011000500014

Faoro, I. D., \& Orth, A. I. (2010). The pear tree culture in Brazil. Revista Brasileira de Fruticultura, 32(1). https://doi.org/10.1590/S0100-29452010000100001

Ferreira, J. P. D. L., Castro, D. S. D., Moreira, I. D. S., Silva, W. P. D., Figueirêdo, R. M., \& Queiroz, A. J. D. M. (2020). Convective drying kinetics of osmotically pretreated papaya cubes. Revista Brasileira de Engenharia Agrícola e Ambiental, 24(3), 200-208. https://doi.org/10.1590/1807-1929/agriambi.v24n3p200-208

Kaleta, A., \& Górnicki, K. (2010). Evaluation of drying models of apple (var. McIntosh) dried in a convective dryer. International Journal of Food Science and Technology, 45(5), 891-898. https://doi.org/10.1111/j.1365-2621.2010.02230.x

Kaya, A., Aydin, O., \& Dincer, I. (2010). Comparison of experimental data with results of some drying models for regularly shaped products. Heat and mass transfer, 46(5), 555-562. https://doi.org/10.1007/s00231-010-0600-z

Lima, L. S. L., Silva, W. P., Pereira, J. C. A., Gomes, J. P., Silva, C. C. D. P. S., \& Silva Júnior, A. F. (2020). Description of continuous and intermittent drying of sapodilla with elimination of tempering period: saving in drying time. Sylwan, 164(2), 444-459.

Luikov, A. V. (1968). Analytical heat diffusion theory. London: Academic Press. 
Maliska, C. R. (2004). Transferência de calor e mecânica dos fluidos computacional. Rio de Janeiro: LTC Editora S.A., p. 453.

Mercali, G. D., Tessaro, I. C., Norena, C. P. Z., Marczak, L. D. F. (2010). Mass transfer kinetics during osmotic dehydration of bananas (Musa sapientum, shum.). International Journal of Food Science and Technology, 45(11), 2281-2289. https://doi.org/10.1111/j.1365-2621.2010.02418.x

Pakowski, Z., \& Mujumdar, A. S. (2007). Drying of Pharmaceutical Products (Chapter 29), In: Handbook of Industrial Drying, Taylor \& Francis Group. https://doi.org/10.1201/b17208

Patankar, S. V. (1980). Numerical heat transfer and fluid flow. New York: Hemisphere Publishing Coorporation, p.197.

Pereira, J. C. A., Silva, W. P., Gomes, J. P., Queiroz, A. J. M., Figueirêdo, R. M. F., Melo, B. A., ... \& Macedo, A. D. B. (2020). Continuous and Intermittent Drying of Rough Rice: Effects on Process Effective Time and Effective Mass Diffusivity. Agriculture, 10(7), 282. https://doi.org/10.3390/agriculture10070282

Putranto, A., Chen, X. D., Devahastin, S., Xiao, Z., \& Webley, P. A. (2011). Application of the reaction engineering approach (REA) for modeling intermittent drying under time-varying humidity and temperature. Chemical Engineering Science, 66(10), 2149-2156. https://doi.org/10.1016/j.ces.2011.02.025

Revista Cultivar (2020). Cultivar Hortaliças e Frutas. Desafios para expansão da produção da pera. Available at

https://www.grupocultivar.com.br/noticias/desafios-para-expansao-da-producao-da-pera

Silva, F. A. S., \& Azevedo, C. A. V. (2016). The Assistat Software Version 7.7 and its use in the analysis of experimental data. Afr. Journal of Agricultural Research, 11(39), 3733-3740. https://doi.org/10.5897/AJAR2016.11522

Silva, W. P., \& Silva, C. M. D. P. S. (2009a). LAB Fit Curve Fitting Software, v. 7.2.46 Available at http://www.labfit.net/

Silva, W. P., \& Silva, C. M. D. P. S. (2009b). "Convective” software. Available at http://zeus.df.ufcg.edu.br/labfit/Convective.htm

Silva, W. P., Galvão, I. B., Silva, C. M. D. P. S., Aires, J. E. F., \& Figueirêdo, R. M. F. (2020). Empirical model for describing continuous and intermittent drying kinetics of apple pieces. Heat Mass Transfer, 56, 1263-1274. https://doi.org/10.1007/s00231-019-02785-w

Silva, W. P., Precker, J. W., Silva, C. M. D. P. S., \& Gomes, J. P. (2009). Determination of effective diffusivity and convective mass transfer coefficient for cylindrical solids via analytical solution and inverse method: Application to the drying of rough rice. Journal Food Engineering, 98, 302-308. https://doi.org/10.1016/j.jfoodeng.2009.12.029

Silva, W. P., Rodrigues, A. F., Silva, C. M. D. P. S., Castro, D. S., \& Gomes, J. P. (2015). Comparison between continuous and intermittent drying of whole bananas using empirical 


\section{Macrothink}

Journal of Agricultural Studies

ISSN 2166-0379 2022, Vol. 10, No. 1

and diffusion models to describe the processes. Journal of Food Engineering, 166, 230-236. https://doi.org/10.1016/j.jfoodeng.2015.06.018

Silva, W. P., Silva, C. M. D. P. S., Farias, V. S. O., \& Gomes, J. P. (2012). Diffusion models to describe the drying process of peeled bananas: optimization and simulation. Drying Technology, 30(1), 64-174. https://doi.org/10.1080/07373937.2011.628554

Silva, W. P., Silva, C. M. D. P. S., Gama, F. J. A., \& Gomes, J. P. (2013). Mathematical models to describe thin-layer drying and to determine drying rate of whole bananas. Journal of the Saudi Society of Agricultural Sciences, 13, 67-74. https://doi.org/10.1016/j.jssas.2013.01.003

Stenström, S. (2020). Drying of paper: A review 2000-2018. Drying Technology, 38(7), 825-845.

\section{Copyright Disclaimer}

Copyright for this article is retained by the author(s), with first publication rights granted to the journal.

This is an open-access article distributed under the terms and conditions of the Creative Commons Attribution license (http://creativecommons.org/licenses/by/4.0/). 